\title{
The Relation of Acid Fast Bacilli with Ziehl Neelsen Staining and Histopathologic Examination of Biopsy Specimens in Extrapulmonary TB Suspected Patients
}

\author{
Yani Triyani, ${ }^{1}$ Maya Tejasari, ${ }^{2}$ Wida Purbaningsih,,${ }^{2}$ Sadeli Masria, ${ }^{3}$ Titik Respati ${ }^{4}$ \\ ${ }^{1}$ Department of Clinical Pathology, ${ }^{2}$ Department of Histology, ${ }^{3}$ Department of Microbiology, \\ ${ }^{4}$ Department of Public Health, Faculty of Medicine, Universitas Islam Bandung, Bandung, Indonesia
}

\begin{abstract}
Case finding and diagnosis of extrapulmonary tuberculosis (EPTB) infection are difficult to enforce in the field because not all primary services can do it. The 2016 TB Health Guidelines, the diagnosis of EPTB, is made by clinical, bacteriological, and or histopathological examination from the biopsy. This study analyzed tissue biopsy histopathologically and bacterial of acid-fast bacilli (AFB) slide stained (by Ziehl Neelsen method) associated with histopathological features in patients diagnosed with EPTB. The study conducted in the laboratory of Al Islam Hospital Bandung from November to December 2017. Histopathological diagnosis collected from 1,304 patients, with 760 noninfectious disease patients (58\%), 461 infectious disease patients (35\%), and $83(7 \%)$ infectious and non-infectious patients. EPTB found in $10 \%$ of infectious disease patients. EPTB was mostly originating in neck lymph nodes (18 of 37 patients). The histopathological diagnosis of EPTB infection found that 36 of 37 patients showed granulomas (+), but AFB stained (+) found only in 6 of 37 slides. It is possible because of granulomas is a collection of several inflammatory cells. The lesions develop granulomatous defined by necrosis. There are fewer organisms that usually exist on the periphery both inside and outside the site of infection. This important immune reaction provides the body with protection from antigen recognition, very important in the case of mycobacterial infections. In conclusion, there is no relation between AFB and histopathological examination in patients with EPTB.
\end{abstract}

Key words: AFB slide Ziehl Neelsen stained, extrapulmonary tuberculosis, granuloma

\section{Hubungan antara Basil Tahan Asam Pewarnaan Ziehl Neelsen dan Hasil Pemeriksaan Histopatologi pada Preparat Jaringan Biopsi Pasien Tuberkulosis Ekstraparu}

\begin{abstract}
Abstrak
Penemuan kasus dan diagnosis infeksi tuberkulosis ekstraparu (TBEP) sulit ditegakkan di lapangan karena tidak semua layanan primer dapat melakukannya. Berdasar atas Pedoman Kesehatan TB 2016 untuk Pengendalian TB, diagnosis TBEP dapat dilakukan dengan pemeriksaan klinis, bakteriologis, dan atau histopatologis dari biopsi. Penelitian ini menganalisis semua sediaan histopatologis dari biopsi jaringan dan menganalisis pemeriksaan bakteriologis pewarnaan basil tahan asam (BTA) (dengan metode Ziehl Neelsen) terkait dengan gambaran histopatologis pada pasien yang didiagnosis TBEP. Penelitian dilaksanakan di Laboratorium RS Al Islam Bandung dari November hingga Desember 2017. Diperoleh 1.304 pasien dengan sediaan histopatologis, diagnosis penyakit noninfeksi 760 pasien (58\%), penyakit infeksi 461 pasien (35\%), penyakit gabungan (infeksi dan noninfeksi) 83 pasien (7\%), serta TBEP 10\% dari seluruh penyakit infeksi. Sebagian besar TBEP berasal dari kelenjar getah bening leher (18 dari 37 pasien). Hasil diagnosis infeksi TBEP 36 dari 37 pasien ditemukan gambaran histopatologisnya dengan granuloma (+), tetapi dengan pewarnaan BTA (+) hanya 6 dari 37 sediaan. Hal ini mungkin karena granuloma adalah kumpulan beberapa sel inflamasi yang berkembang menjadi nekrosis sehingga lebih sedikit organisme yang biasanya terdapat di dalam maupun di luar lesi. Pembentukan granuloma merupakan reaksi kekebalan yang memberi perlindungan tubuh dari serangan antigen dalam kasus infeksi mikobakterium. Simpulan, tidak terdapat hubungan hasil pewarnaan BTA dengan pemeriksaan histopatologis pada pasien TBEP.
\end{abstract}

Kata kunci: Granuloma, sediaan BTA pewarnaan Ziehl Neelsen, tuberkulosis ekstraparu 


\section{Introduction}

Based on the report of the World Health Organization (WHO) in 2019 reported about 7 million cases of tuberculosis (TB) had received treatment in the world each year, with a mortality rate of 1.5 million in 2018. Tuberculosis remains an infectious disease as the highest killer globally. ${ }^{1}$ Indonesia is in the list of 30 countries with the highest tuberculosis burden and ranks third highest in the world in terms of tuberculosis incidence. The incidence of tuberculosis in Indonesia in 2018 is 316 per 100 , ooo population, with an estimated TB case of 845,000 cases per year and notification of TB cases of 570,289 cases, so there are still around $32 \%$ of cases that have not been verified either unreached, undetected or unreported. It is necessary to change the TB patient discovery strategy from passive to active. Intensive and massive family-based and community-based discovery recommended while still paying attention and maintaining the quality of the TB program. ${ }^{2}$ The TB case finding programs have carried out for the problem of pulmonary TB. However, it should be noted that in addition to the pulmonary TB mentioned above, TB does not only attack the lungs, but it can also attack other organs besides the lungs. Extrapulmonary tuberculosis (EPTB) occurs in about $15 \%$ of the 6.3 million cases based on WHO data in 2016 . The incidence of EPTB varies in various regions ranging from $8-34 \%$ of all TB cases. Of these, $16 \%$ are children under the age of 15 years. EPTB rates vary significantly according to the country's socioeconomic level and the resources specific to the TB program. ${ }^{3,4}$ Many risk factors can influence the occurrence of a person suffering from EPTB including host immunological response factors, socio-demographic, comorbidity, genetic factors, lymph node pathogenesis, lifestyle behaviors, previous history of pulmonary TB, noncompliance with taking anti-TB drugs, failure of therapy either due to drug resistance or incorrect diagnosis. ${ }^{3,5,6}$

Based on several studies to help establish the diagnosis of EPTB found from fine-needle aspiration biopsy (FNAB) biopsy or tissue biopsy, the researcher can use a simple examination with Ziehl Neelsen's (ZN) staining method. ${ }^{7,8}$ This examination is an effective and simple technique with a high degree of accuracy in diagnosing EPTB, such as TB lymphadenitis. Despite various limitations, the ZN staining method can be used as the first choice in cases with EPTB in developing countries with a high prevalence of tuberculosis. Acid-fast bacilli (AFB) stain ZN method despite low sensitivity, but this method must be carried out routinely in patients suspected of EPTB, especially in developing countries, because sophisticated laboratory equipment is not available. $^{8-14}$

The amount of AFB in the Ziehl Neelsen's BTA examination derived from sputum material to establish a diagnosis of pulmonary TB reported using the scale of the international union against tuberculosis and lung disease (IUATLD), with degrees of positivity $+1,+2$, and +3 according to the number of AFB found each field of a light microscope with magnification 1,000 times. BTA examination of tissue is different from BTA examination originating from sputum, there is no standard scale used to assess the degree of positivity, so it still requires further research..$^{8-10}$ Tuberculin test or interferon-gamma release assay (IGRAs) tests determine exposure to MTB, but cannot distinguish between active and latent TB. Culture remains the gold standard, but it takes 8-10 weeks to obtain results, and its sensitivity depends on the host and source of the specimen. ${ }^{15^{-19}}$

This study aims to analyze the use of AFB stain with the Ziehl Neelsen's method of tissue biopsy specimens (paraffin blocks) in patients suspected of EPTB by the results histopathologic exam and assess the relationship of clinical symptoms to help establish the diagnosis of EPTB.

\section{Methods}

This research conducted in the laboratory of Al Islam Hospital Bandung from November to December 2017. This research was conducted through 4 phases which are phase 1 of the study aimed to identify the characteristics of sex and age and the diagnosis of histopathological interpretation of patients from all paraffin blocks examined during 2017, byanalyzing the proportion of infectious, non-infectious and non-infectious diseases. Furthermore, histopathological analysis of infection is identified with TB (specific process) or non-specific process.

Phase 2 of this study made three new preparations from the paraffin block diagnosed with TB infection. Two slides stained with Ziehl Neelsen's AFB staining method and one slide kept as an archive.

Phase 3 of this study reads slides that are stained with smear using a $1,000 \times$ microscope using 


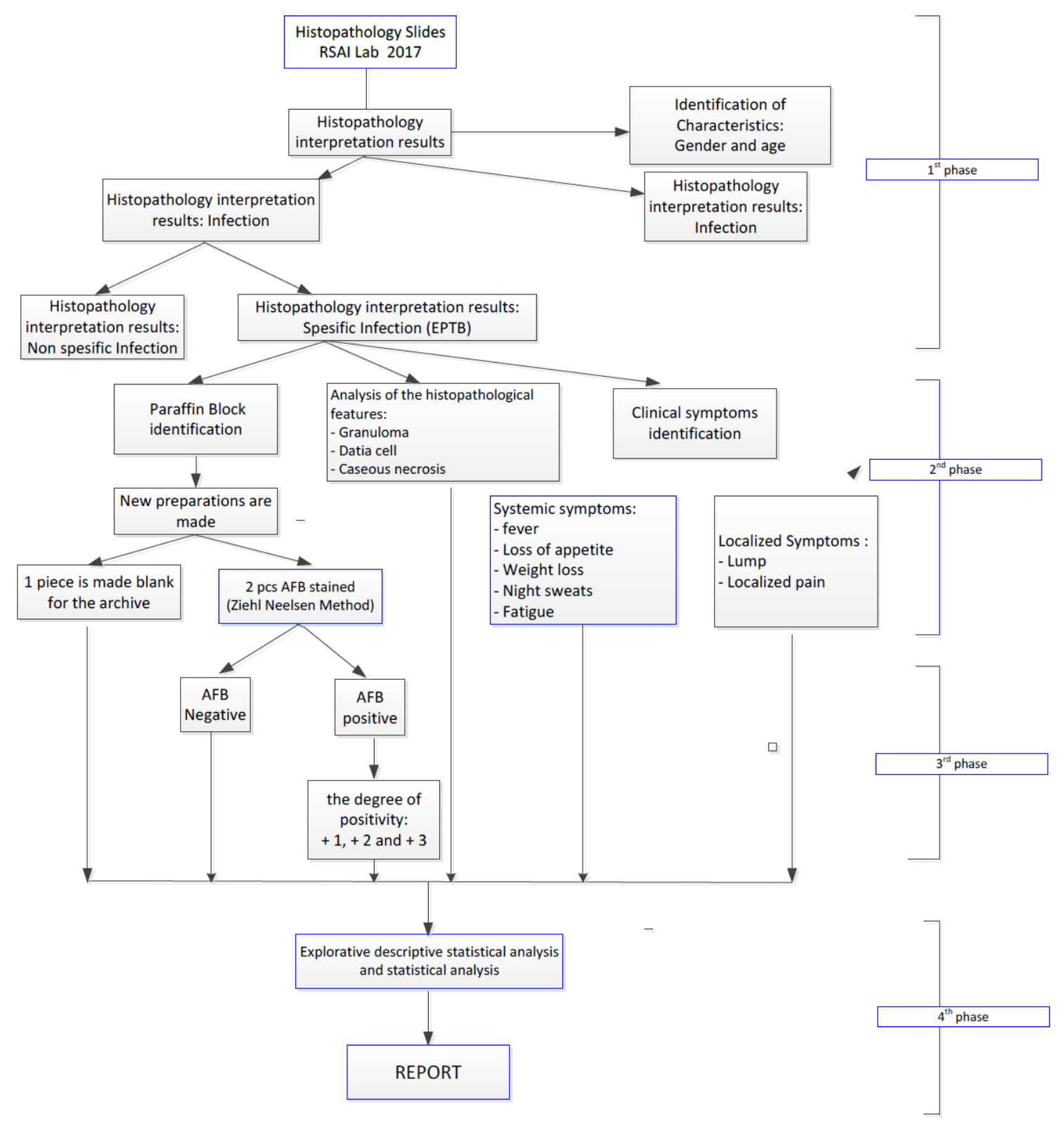

Figure 1 Research Procedure

emersion oil and documented using a microscope camera (Optilab) with the international union's calculation against tuberculosis and lung disease (IUATLD) scale modification.

Phase 4 of this study collected and processed statistics from medical record data to assess patient characteristics, related to the degree of positivity of tissue biopsy preparations, the clinical symptoms of both localized and systemic patients from all patients with histopathological diagnosis of infection with specific processes (EPTB). The research procedure can be seen schematically in the chart in Figure 1.

This study was approved by the Health Research Ethics Committee of the Faculty of Medicine, Universitas Islam Bandung, Indonesia No. 362/Ethics Committee.FK/XII/2017.

\section{Results}

This paper will only present and analyze phases $1-3$ of the entire study. The results of phase 1 were histopathological diagnoses collected from 1,304 patients. The measured variables are gender 
Table 1 Biopsied Patients Characteristic

\begin{tabular}{ccccc}
\hline $\begin{array}{c}\text { Age } \\
\text { (Year) }\end{array}$ & $\begin{array}{c}\text { Female } \\
(\mathbf{n = 8 1 3})\end{array}$ & $\begin{array}{c}\text { Male } \\
(\mathbf{n = 4 9 1})\end{array}$ & $\begin{array}{c}\text { Total } \\
(\mathbf{n = 1 , 3 0 4})\end{array}$ & \% \\
\hline $0-4$ & 12 & 14 & 26 & 2 \\
$5-10$ & 8 & 11 & 19 & 1 \\
$10-14$ & 22 & 14 & 36 & 3 \\
$15-19$ & 80 & 24 & 104 & 8 \\
$20-4$ & 100 & 32 & 132 & 10 \\
$25-29$ & 76 & 20 & 96 & 7 \\
$30-34$ & 93 & 32 & 125 & 10 \\
$35-39$ & 102 & 31 & 133 & 10 \\
$40-44$ & 80 & 27 & 107 & 8 \\
$45-49$ & 83 & 36 & 119 & 9 \\
$50-54$ & 64 & 40 & 104 & 8 \\
$55-59$ & 27 & 40 & 67 & 5 \\
$60-64$ & 30 & 44 & 74 & 6 \\
$65-70$ & 12 & 39 & 51 & 4 \\
$70-75$ & 15 & 39 & 54 & 4 \\
$>75$ & 9 & 48 & 57 & 5 \\
\hline
\end{tabular}

(female and male), disease diagnosis (infectious, non-infectious, and combined), and age group (adjusted for age grouping used for population pyramid). Data processing carried out with SPSS 24 , and the results obtained were more female patients, namely 813 (62\%) people compared to 491 (38\%) male patients. Based on the gender of women in the two age groups, namely 20-24 years and 35-39 years, each of which was 101 patients (Table 1 ).

From Table 1, it can be seen that females had a higher percentage of having infectious diseases and are non-infectious. In females, 267 patients diagnosed with infectious diseases, 291 patients diagnosed with non-infectious diseases, and 55 patients diagnosed with infectious and non-infectious diseases. On the other hand, in men diagnosed with infectious, non-infectious diseases, and a combined of 194 patients, 269 patients, and 28 patients, this can be seen in the picture above. Based on the proportion of age groups at each disease diagnosis (infectious, noninfectious, and combined). In patients diagnosed with infectious diseases, the largest age group was the 35-39-year group, and the least was the o-4-year group with five patients. Furthermore, in the group of patients diagnosed with noninfectious diseases, the age group of 20-24 years occupies the first position with 76 patients, while the 5-9 years age group occupies the last position with a total of eight patients. Complicated or
Table 2 Characteristics of EPTB Patients at Al Islam Hospital 2017

\begin{tabular}{|c|c|}
\hline EPTB Patients & $\mathbf{n}=\mathbf{3 7}$ \\
\hline \multicolumn{2}{|l|}{ Age (years) } \\
\hline$<20$ & 3 \\
\hline $20-29$ & 7 \\
\hline $30-39$ & 14 \\
\hline $40-49$ & 4 \\
\hline $50-59$ & 5 \\
\hline $60-69$ & 3 \\
\hline$\geq 70$ & 1 \\
\hline \multicolumn{2}{|l|}{ TB history } \\
\hline No data & 14 \\
\hline Negative & 18 \\
\hline Positive & 5 \\
\hline \multicolumn{2}{|l|}{ Organ } \\
\hline Axilla lymph node & 2 \\
\hline Neck lymph node & 18 \\
\hline Mesenteric lymph node & 1 \\
\hline Inguinal lymph node & 1 \\
\hline Submandibular lymph node & 1 \\
\hline Supraclavicular lymph node & 1 \\
\hline Axilla and mammae lymph node & 1 \\
\hline Mammae & 2 \\
\hline Peritoneum & 1 \\
\hline Renal & 1 \\
\hline Muscle & 1 \\
\hline Bone & 1 \\
\hline Joint & 2 \\
\hline Bladder & 2 \\
\hline Testis & 2 \\
\hline \multicolumn{2}{|l|}{ AFB results } \\
\hline No data & 5 \\
\hline$(-)$ & 26 \\
\hline$(+)$ & 6 \\
\hline
\end{tabular}

Histopathologic feature

No granuloma 1

Positive granuloma 36

Systemic clinical manifestations fever Yes

No 30

Night sweat

Yes 2

No $\quad 35$

Fatique

Yes 2

No 35

Weight loss

Yes 2

No 35

Local manifestation (lump/pain)

Yes $\quad 37$

No $\quad 37$ 


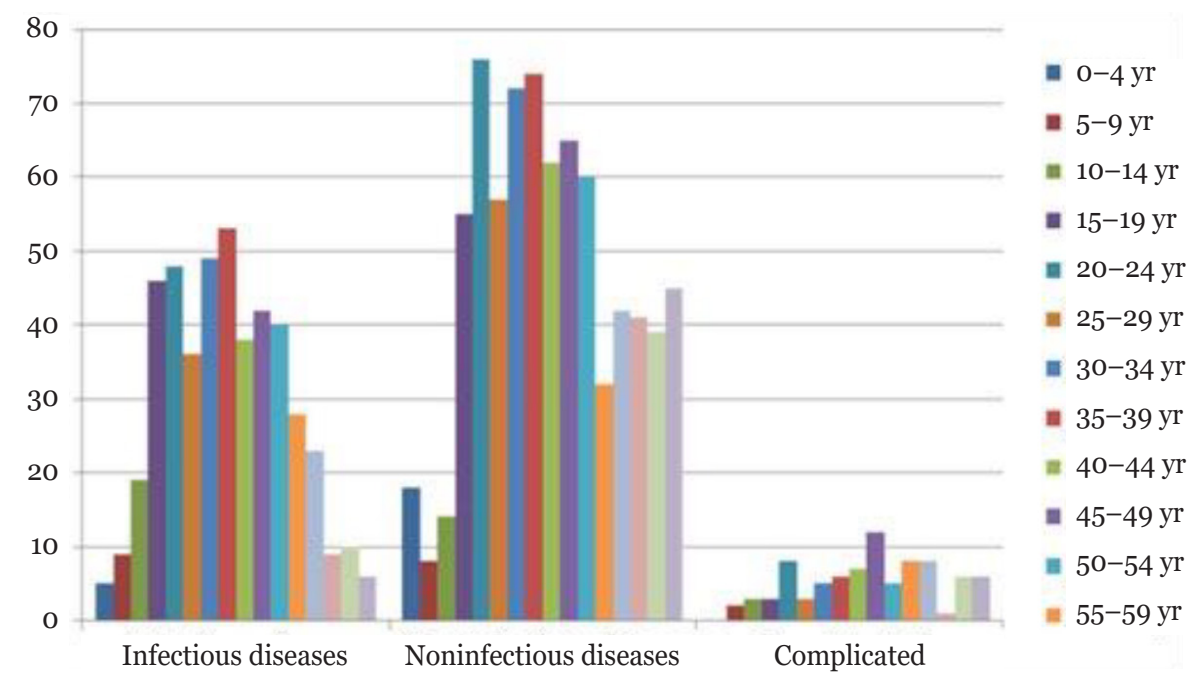

Figure 2 Patients Diagnosed based on Biopsies

patients diagnosed with both infectious and noninfectious diseases, the diagnosis is mostly in the age group 45-49 years as many as 12 people and at least one person in the age group 65-69 years, this can be seen in the graph as follows Figure 2.

Biopsy data from Al Islam Hospital Bandung in 2017 found that 461 patients diagnosed with infections. The variables measured were gender (female and male), age group, and organ origin. Figure 2 shows the gender distribution of patients from the biopsy results showing female patients (58\%) more than male patients (42\%). Based on the age group diagnosed with an infectious disease, both men and women in the age group $30-39$ years were 43 people and 59 , respectively.

The results of data collection phase 1 on the diagnose of infectious diseases based on the histopathological interpretation of tissue biopsy from 461 people. A classification of diagnoses between non-specific and specific infections (EPTB) was from the total number of the histopathological interpretation. Forty-four people (10\%) of the total samples were diagnosed with infectious diseases with specific infections (EPTB).

The phase of this study aims to describe the characteristics of patients with diagnosis based on histopathological interpretation of ЕРТВ infection according to age, gender, previous history of TB, clinical manifestations of the systemic and localized nodule, AFB results, and the histopathology.

A total of 44 patients diagnosed as EPTB sufferers based on diagnostic supporting data such as medical records, $\mathrm{AFB}$ results, and ascertaining the histopathological picture. After collecting the supporting data, only 37 patients data were valid and can be used for further analysis. The results of 37 data are as follows.

General description based on sex in patients diagnosed with EPTB or process-specific infections found the proportion of female patients diagnosed with EPTB was higher (62\%) than male patients (38\%). General characteristics of ЕРTB patients at $\mathrm{Al}$ Islam Hospital in 2017, obtained data that EPTB patients have the most age in the age group 30-39 years with only 5 of 37 patients who have a history of previous TB. Most of the EPTB occurred originating in neck lymph nodes (18 of 37 patients), while other organs' origin was quite balanced in only one or two events.

Phase 3 research results: this research stage reads preparations that have been stained with BTA staining using a $1,000 \times$ microscope using emersion oil and documented using a microscope camera (Optilab) to calculate the IUATLD scale modification.

After judging from the results of AFB slides from the patient's tissue biopsy, only five people diagnosed positive were AFB. Details of three patients having AFB 10-100/100 visual fields, two people with 1-10 per visual field, and one person saw BTA is more than 10 per one field of view. Judging from the histopathological picture, almost all TEBP patients showed granulomas (36 of 37 patients). The explanation of the characteristics and clinical symptoms of EPTB patients can be seen in Table 2 . 
The degree of smear positivity of the paraffin block slides AFB stain uses a modified international union against tuberculosis and lung disease (IUATLD) scale on the sputum smear. However, no literature explains, because it is different from smear from sputum smear test material can be homogeneous. At the same time, slides stained from the paraffin block cannot be homogenized because the slides come from tissue that is not possible to homogenize beforehand. So that the data presented is positive or negative.

\section{Discussion}

Based on data from all interpretations of the histopathological diagnosis treated as many as 1,304 patients, the female sex characteristics variable is more than 813 patients (62\%) compared to male patients (491 patients) $38 \%$. While based on the characteristics of age, the most occurred in 20-39 years. It is different from the Riskesdas data, which states that women are usually at the age of 40-60 years of age, is a crisis period for women, is reaching a career peak, and precisely at that time they will experience menopause (ages 45-55 years). Menopausal conditions can reduce the production of female hormones (estrogen and progesterone). With the decline, the distribution of body fat begins disrupted. The accumulation of fat that is not well distributed will affect the body's metabolism. If this process followed by a prolonged diet, lifestyle, and unhealthy activities, then the highest age of malignancy is 55-64 years. Individuals will be vulnerable to degenerative diseases. The histopathological diagnosis found in a shift in the incidence of noninfectious diseases more than infectious diseases. It follows the Indonesia Health Profile 2018 data, which states that non-infectious diseases are now beginning to increase. The ten prominent diseases causing the highest death being stroke, and cardiovascular disease, while malignancy is ranked seventh. The highest cause of death from Infectious disease is tuberculosis (TB). However, it is still ranked $4^{\text {th }}$ from the cause of death in general. The eradication of $\mathrm{TB}$ is still experiencing obstacles because TB infection, besides attacking the lung, can also attack all organs in the human body, especially in lymph nodes. Case finding and treatment of TB that attacks the pulmonary organ have progressed, although the threat of multi-drug and extensive drug-resistant is still challenging to solve. ${ }^{21,22}$

The discovery of TB diagnosis and therapy outside the pulmonary organ is still an obstacle at this time; the study results obtained 5 of 37 patients with a history of TB before experiencing EPTB infection. A diagnostic grouping makes between specific infections (EPTB) and nonspecific non-EPTB infections from the total diagnosis of the histopathological interpretation results. This study found that $10 \%$ of the total diagnoses of infectious diseases were diagnoses of infection with a specific process (EPTB).

Most of the EPTB occurred originating in neck lymph nodes 18 of 37 patients while the rest evenly spread from other organs, including bones, breasts, perianal, ileum. It is consistent with studies in other developing countries that previously reported the most common location of EPTB is in lymph nodes. $3,8,14,21,22$

Based on the Regulation of the Minister of Health Republic of Indonesia (Permenkes) No. 67 the Year 2016, the diagnosis of extrapulmonary TB (EPTB) includes history taking, physical examination, histopathological and bacterial examination. The result found the histopathological diagnosis of EPTB in 36 of 37 patients with granulomas (+). However, smear $(+)$ found only in 6 out of 37 patients. It is possible because granulomas are a collection of several inflammatory cells, especially mature macrophages that form aggregates in response to an antigen. Antigens can come from a bacterium, fungus, foreign body, and from the immune complex. The purpose of granuloma formation is to isolate the antigen from the host body and facilitate the eradication of the antigen. Granuloma formation, antigen-presenting cells express a variety of pro-inflammatory and chemopractical cytokines. Recruitment of neutrophils from circulation to the site of infection and an increase in cytokines invokes and activates monocytes. Under normal circumstances, neurophilic recruitment alone eliminates infectious agents, through phagocytosis and digestion in vacuoles. During the initial infection, when only one infection, there is an organism in the mononuclear cell. Granulomas defined by necrosis. There are fewer organisms that usually exist on the periphery both inside and outside the body. This critical immune reaction provides the body with protection from antigen recognition, very important in the case of mycobacterial infections..$^{23-25}$

Immune disorders, especially the innate immune system (innate immunity), cause the granuloma not correctly formed (poor 
granulomas). Poor granulomas also occur in TNF- $\alpha$ deficiency, Interleukin-12 (IL-12), or gamma Interferon (IFN- $\gamma$ ). The role of cytokine relates to systemic clinical manifestations, such as fever, night sweats, fatigue, and weight loss. They are not very meaningful for ЕРTB because the incidence is only $2-7$ out of 37 patients. It is different from local manifestations complained by all patients with a diagnosis of EPTB based on histopathology. The histopathological examination of EPTB is almost entirely with (+) granulomas. Previous research explains that the granuloma picture is typical in TB-infected tissue, ${ }^{8,9,23}$ and the others research found the sensitivity of bacterial smear microscopy (AFB tissue biopsy staining) found in $51 \%$ reported by Vadwai et al., ${ }^{26} 33.3 \%$ reported by $\mathrm{Al}$ Ateah et al. ${ }^{27}$ and $28.6 \%$ reported by Malbruny et al. ${ }^{28}$ Prospective research conducted to screen patients with systemic and local symptoms that led to the infection of specific processes from the start of the testing biopsy test material. In addition to histopathological examination, slide block paraffin AFB staining was also done with more accurate monitoring of clinical manifestations.

\section{Conclusion}

There is no relationship between the results of AFB (Ziehl Nielsen stained) and the histopathological examination in patients with extrapulmonary TB.

\section{Conflict of Interest}

There is no conflict of interest at all authors.

\section{References}

1. World Health Organization. Global tuberculosis report 2019. Geneva, Switzerland: World Health Organization; 2019.

2. Direktorat Jenderal Pencegahan dan Pengendalian Penyakit Kementerian Kesehatan Republik Indonesia. Panduan peringatan hari tuberkulosis sedunia tahun 2020 [Internet]. Jakarta: Kementerian Kesehatan Republik Indonesia; 2020 [cited 2020 June 30]. Available from: https://dinkes.jatimprov.go.id/userimage/ dokumen/juknis-htbs-beserta-juknispenemuan-kasus_final.pdf.

3. Ayed HB, Koubaa M, Marrakchi C, Rekik K, Hammami F, Smaoui F, et al. Extrapulmonary tuberculosis: update on the epidemiology, risk factors and prevention strategies. Int $J$ Trop Dis. 2018;1(1):006.

4. Khan AH, Sulaiman SAS, Laghari M, Hassali MA, Muttalif AR, Bhatti Z, et al. Treatment outcomes and risk factors of extra-pulmonary tuberculosis in patients with co-morbidities. BMC Infect Dis. 2019;19(1):691.

5. Prozorov AA, Fedorova IA, Bekker OB, Danilenko VN. The virulence factors of Mycobacterium tuberculosis: genetic control, new conceptions. Russ J Genet. 2014;50(8):775-97.

6. Cantres-Fonseca OJ, Rodriguez-Cintrón W, Olmo-Arroyo FD, Baez-Corujo S. Extra pulmonary tuberculosis: an overview [e-book]. In: Chauhan NS, editor. Role of microbes in human health and diseases. London, UK: IntechOpen Ltd.; 2018 [cited 2020 June 30]. Available from: https:// www.intechopen.com/books/role-ofmicrobes-in-human-health-and-diseases/ extra-pulmonary-tuberculosis-an-overview.

7. Peraturan Menteri Kesehatan Republik Indonesia Nomor 67 Tahun 2016 tentang Penanggulangan Tuberkulosis.

8. Nassaji M, Azarhoush R, Ghorbani R, Kavian F. Acid fast staining in formalin-fixed tissue specimen of patients with extrapulmonary tuberculosis. IJSRP [Internet]. 2014 [cited 2020 July 1];4(10):P343200. Available from: http://www.ijsrp.org/research-paper-1014. php?rp=P343200.

9. Laga AC, Milner DA Jr, Granter SR. Utility of acid-fast staining for detection of mycobacteria in cutaneous granulomatous tissue reactions. Am J Clin Pathol. 2014; 141(4):584-6.

10. Fukunaga H, Murakami T, Gondo T, Sugi K, Ishihara T. Sensitivity of acid-fast staining for Mycobacterium tuberculosis in formalinfixed tissue. Am J Respir Crit Care Med. 2002;166(7):994-7.

11. Purohit M, Mustafa T. Laboratory diagnosis of extra-pulmonary tuberculosis (EPTB) in resource-constrained setting: state of the art, challenges and the need. J Clin Diagn Res. 2015;9(4):EE01-6.

12. Reddy S, Brown T, Drobniewski F. Detection of Mycobacterium tuberculosis from paraffin-embedded tissues by INNO-LiPA Rif.TB assay: retrospective analyses of Health Protection Agency National Mycobacterium Reference Laboratory data. J Med Microbiol. 
2010;59(Pt 5):563-6.

13. Tadesse M, Abebe G, Abdissa K, Bekele A, Bezabih M, Apers L, et al. Concentration of lymph node aspirate improves the sensitivity of acid fast smear microscopy for the diagnosis of tuberculous lymphadenitis in Jimma, southwest Ethiopia. PLoS One. 2014;9(9):e106726.

14. Pollett S, Banner P, O'Sullivan MVN, Ralph AP. Epidemiology, diagnosis and management of extra-pulmonary tuberculosis in a low-prevalence country: a four year retrospective study in an Australian tertiary infectious diseases unit. PLoS One. 2016;11(3):e0149372.

15. Topić RZ, Dodig S, Zoričić-Letoja I. Interferon $-\gamma$ and immunoglobulins in latent tuberculosis infection. Arch Med Res. 2009;40(2):103-8.

16. Britton WJ, Gilbert GL, Wheatley J, Leslie D, Rothel JS, Jones SL, et al. Sensitivity of human gamma interferon assay and tuberculin skin testing for detecting infection with Mycobacterium tuberculosis in patients with culture positive tuberculosis. Tuberculosis. 2005;85(3):137-45.

17. Zhou XX, Liu YL, Zhai K, Shi HZ, Tong ZH. Body fluid interferon- $\gamma$ release assay for diagnosis of extrapulmonary tuberculosis in adults: a systematic review and metaanalysis. Sci Rep. 2015;5:15284.

18. Álvarez J, de Juan L, Bezos J, Romero B, Sáez JL, Marqués S, et al. Effect of paratuberculosis on the diagnosis of bovine tuberculosis in a cattle herd with a mixed infection using interferon-gamma detection assay. Vet Microbiol. 2009;135(3-4):389-93.

19. Harada N, Higuchi K, Yoshiyama T, Kawabe Y, Fujita A, Sasaki Y, et al. Comparison of the sensitivity and specificity of two whole blood interferon-gamma assays for M. tuberculosis infection. J Infect. 2008;56(5):348-53.

20. Badan Penelitian dan Pengembangan
Kesehatan Kementerian Kesehatan Republik Indonesia. Hasil utama Riskesdas 2018 [Internet]. Jakarta: Kementerian Kesehatan Republik Indonesia; 2018 [cited 2020 July 2]. Available from: https://www.kemkes. go.id/resources/download/info-terkini/ hasil-riskesdas-2018.pdf.

21. Wani RLS. Clinical manifestations of pulmonary and extra-pulmonary tuberculosis. SSMJ. 2013;6(3):52-6.

22. Lee JY. Diagnosis and treatment of extrapulmonary tuberculosis. Tuberc Respir Dis (Seoul). 2015;78(2):47-55.

23. Shah KK, Pritt BS, Alexander MP. Histopathologic review of granulomatous inflammation. J Clin Tuberc Other Mycobact Dis. 2017;7:1-12.

24. Yoon HJ, Song YG, Park WI, Choi JP, Chang $\mathrm{KH}$, Kim JM. Clinical manifestations and diagnosis of extrapulmonary tuberculosis. Yonsei Med J. 2004;45(3):453-61.

25. Popescu MR, Călin G, Strâmbu I, Olaru M, Bălăşoiu M, Huplea V, et al. Lymph node tuberculosis-an attempt of clinicomorphological study and review of the literature. Rom J Morphol Embryol. 2014;55(2 Suppl):553-67.

26. Vadwai V, Boehme C, Nabeta P, Shetty A, Alland D, Rodrigues C. Xpert MTB/RIF: a new pillar in diagnosis of extrapulmonary tuberculosis? J Clin Microbiol. 2011;49(7): 2540-5.

27. Al-Ateah SM, Al-Dowaidi MM, El-Khizzi NA. Evaluation of direct detection of Mycobacterium tuberculosis complex in respiratory and non-respiratory clinical specimens using the Cepheid Gene Xpert ${ }^{\circledR}$ system. Saudi Med J. 2012;33(10):1100-5.

28. Malbruny B, Le Marrec G, Courageux K, Leclercq R, Cattoir V. Rapid and efficient detection of Mycobacterium tuberculosis in respiratory and non-respiratory samples. Int J Tuberc Lung Dis. 2011;15(4):553-5. 